\title{
Patient with Recurrent Glioblastoma Responding Favorably to Ketogenic Diet Combined with Intranasal Delivery of Perillyl Alcohol: A Case Report and Literature Review
}

\section{Paciente com glioblastoma recorrente respondendo positivamente a dieta cetogênica combinada a álcool perílico intranasal: relato de caso e revisão da literatura}

\author{
Clovis Orlando da Fonseca ${ }^{7}$ \\ ${ }^{1}$ Graduate Program in Medical Sciences, Universidade Federal \\ Fluminense, Niteroi, RJ, Brazil \\ 2 Department of Nutrition, Universidade Federal Fluminense, Niteroi, \\ RJ, Brazil \\ ${ }^{3}$ Department of Molecular Microbiology \& Immunology, Keck School \\ of Medicine, University of Southern California, Los Angeles, USA \\ ${ }^{4}$ Department of Experimental Therapeutics, Beckman Research \\ Institute of City of Hope, Duarte, CA91010, USA \\ ${ }^{5}$ Service of Radiology, Department of Radiology, Antonio Pedro University \\ Hospital, Universidade Federal Fluminense, Niteroi, RJ, Brazil \\ 6 Department of Cellular and Molecular Biology, Institute of Biology, \\ Universidade Federal Fluminense, Niteroi, RJ, Brazil \\ 7 Service of Neurosurgery, Department of General and Specialized \\ Surgery, Antonio Pedro University Hospital, Universidade Federal \\ Fluminense, Niteroi, RJ, Brazil,
}

Juliana Guimarães Santos ${ }^{1}$ Wanise Maria Souza Da Cruz ${ }^{2}$ Axel H. Schönthal ${ }^{3}$

Marcela D'alincourt Salazar ${ }^{4}$ Cristina Asvolinsque Pantaleão Fontes ${ }^{5}$ Thereza Quirico-Santos ${ }^{6}$

Address for correspondence Juliana Guimaraes Santos, MSc, MD, Universidade Federal Fluminense, Niterói, Rio de Janeiro, Brazil

Arq Bras Neurocir 2017;36:194-199.
Abstract
Introduction Monoterpene perillyl alcohol (POH) is cytotoxic to temozolomide-
Keywords
- ketogenic diet
- perillyl alcohol
- intranasal administration
- glioblastoma multiforme
- combination therapy
- drug resistance resistant glioma cells, regardless of its O6-methylguanine-methyltransferase (MGMT) promoter methylation status. Moreover, adherence to a ketogenic diet (KD) produced successful outcomes in preclinical and clinical studies in the glioma setting. Case Presentation A 54-year-old Caucasian man had a confirmed diagnosis of refractory glioblastoma multiforme (GBM). The immunohistochemical evaluation was negative for methylation, and failed to detect mutations in the isocitrate dehydrogenase (IDH) 1 and 2 genes. In January 2016, the patient was enrolled in a clinical trial combining daily intranasal delivery of $\mathrm{POH}$ in combination with a KD. The $\mathrm{KD}$ was administered concomitantly with inhalation of $\mathrm{POH}$ ( $55 \mathrm{mg}, 4$ times a day) in an uninterrupted administration schedule for 3 months.

received

June 1, 2017

accepted

July 11,2017

published online

August 10, 2017
Copyright $\odot 2017$ by Thieme Revinter

Publicações Ltda, Rio de Janeiro, Brazil
License terms

(c) (i) $\ominus$ (\$)
$10.1055 / \mathrm{s}-0037-1605588$ ISSN $0103-5355$. 


\section{Resumo}

Palavras-chave

- dieta cetogênica

- álcool perílico

- administração intranasal

- glioblastoma multiforme

- tratamento combinado

- resistência medicamentosa
Results The combination treatment was well-tolerated. The nutritional status and anthropometric measurements of the patient were measured. Adherence to the KD was confirmed by measuring the levels of ketone bodies in the urine. Throughout the treatment, a reduced frequency of seizures was observed. After three months of adherence to the treatment, the patient presented with weight loss, reduced body fat, increased water retention, and a slight increase in bone and muscle mass. A follow-up magnetic resonance imaging (MRI) scan after 3 months of treatment revealed marked reduction of the enhancing lesion.

Conclusion Intranasal delivery of $\mathrm{POH}$ combined with concomitant adherence to a KD appeared to have a beneficial therapeutic effect in a patient with recurrent GBM. Further studies are needed to evaluate the efficacy of this therapeutic strategy in a larger cohort of treatment-refractory GBM patients.

Introdução O monoterpeno álcool perílico (AP) é citotóxico para linhagens celulares de glioblastoma, independentemente do status do promotor de metilação O6-metilguaninametiltransferase (MGMT). Além disso, a adesão à dieta cetogênica (DC) produziu resultados bem sucedidos em desenho de estudos pré-clínicos e clínicos de glioma.

Relato de Caso Homem, 54 anos, caucasiano, com diagnóstico de glioblastoma multiforme (GBM) recidivo. A avaliação imuno-histoquímica foi negativa para metilação e não detectou mutações do gene da isocitrato desidrogenase 1 e 2 (IDH1 IDH2). Em janeiro de 2016, o paciente foi inscrito em um ensaio clínico da administração intranasal diária do AP combinada a DC. A DC foi administrada concomitantemente com inalação de AP (55 mg, 4 vezes ao dia) em um cronograma de administração ininterrupto durante 3 meses.

Resultados O tratamento combinado foi bem tolerado. O estado nutricional e as medidas antropométricas do paciente foram avaliadas. Aderência a DC foi confirmada pela presença de corpos cetônicos na urina. Ao longo do tratamento, observou-se redução da frequência de convulsões. Após três meses de adesão ao tratamento, o paciente apresentou perda de peso, redução da gordura corporal, melhor hidratação e um aumento discreto da massa óssea e muscular. O acompanhamento da ressonância magnética após 3 meses de tratamento revelou redução acentuada do volume da lesão.

Conclusão A administração intranasal do AP combinada a DC sugere ter um efeito terapêutico benéfico em pacientes com GBM recorrente. São necessários mais estudos para avaliar a eficácia desta estratégia terapêutica em uma coorte maior de pacientes com GBM refratários.

\section{Introduction}

Glioblastoma multiforme (GBM) is the most common malignant primary brain tumor. Despite standard-of-care therapy consisting of surgery and chemoradiation therapy, the disease relapses in most patients, and the median survival is only of $\sim 15$ months. ${ }^{1}$ One of the major mechanisms of disease relapse in GBM patients has been attributed to the enhanced ability of poorly differentiated glioma cells to invade and infiltrate surrounding healthy tissue., ${ }^{2,3}$ In this aspect, the vicinity and extension of the peritumoral edema (PTE) can be useful to predict clinical outcomes in patients with a newly-diagnosed malignant glioma. ${ }^{4}$

Epilepsy develops in around $30-50 \%$ of patients with brain tumors as a consequence of the brain swelling due to the edema accompanying the lesion. Epilepsy is a debilitating condition that causes distress and adversely affects the patient's quality of life. ${ }^{5,6}$ Antiepileptic drugs are commonly used to treat these patients; however, such treatments are known to exert detrimental neuropsychological effects and often interact with the therapeutic regimen, such as chemotherapeutic agents. ${ }^{5,7}$ Several studies have attempted to address this issue by analyzing how changes in the peritumoral tissue correlate with the onset of seizures in patients with brain tumors. Mounting evidence suggests that epileptogenesis correlates with metabolic alterations, acidosis and disruption of localized neural networks in the tumoral and peritumoral areas of the brain. ${ }^{8,9}$

Recent studies have suggested that consumption of a ketogenic diet (KD) might play a role in improving the outcomes of cancer patients undergoing treatment and in minimizing the frequency of epileptic episodes. ${ }^{10-13}$ The typical KD consists of 
low amounts of carbohydrates, moderate amounts of protein, and high amounts of fat, aimed at stimulating fat metabolism while minimizing sugar availability. Adherence to a KD promotes a unique metabolic state resulting from elevated levels of fat-derived ketone bodies and lower levels of blood sugar, which have been correlated with improved outcomes in patients with diabetes, cancer and certain neurological disorders. $^{10,14,15}$ In addition, KDs have shown to reduce the frequency and severity of seizures in epileptic patients. ${ }^{12,16}$

In the context of cancer, KDs are presumed to counteract the Warburg effect by depriving tumor cells of glucose and improving mitochondrial activity. ${ }^{10,17}$ The Warburg effect is characterized by a metabolic shift from aerobic respiration toward increased glycolysis and lactate production, despite the availability of oxygen (aerobic glycolysis). ${ }^{18,19}$ Importantly, a major consequence of the Warburg effect is the increased cellular consumption of glucose as the main source of energy. Nevertheless, this glycolytic dependency may provide an opportunity for therapeutic intervention, based on the assumption that a reduction in glucose availability may lead to a decline in proliferation and metastatic capacity, along with increased sensitivity to cytotoxic or targeted therapies. $^{13,19,20}$ The shift in the ratio of ketone bodies over glucose is disadvantageous to tumor cells, since glucose-addicted cancer cells are less likely to utilize ketone bodies for energy, in contrast to normal cells, which can generate energy from either source. ${ }^{21}$

Emerging evidence indicates that KDs may have beneficial effects in patients with malignant glioma. Results from a study in which adherence to a KD was combined with standard chemoradiotherapy in a patient with GBM have demonstrated that the patient went into complete remission while presenting with reduced blood glucose levels. ${ }^{22}$ Subsequent case reports investigating this regimen have also shown a correlation between reduced serum glucose levels and improved therapeutic responses. ${ }^{16,17,23}$ Altogether, there is intriguing evidence correlating KD and metabolic reprogramming with improved therapeutic responses to standard-of-care regimens for the treatment of patients with malignant glioma. ${ }^{13,17}$ We have published extensively on the antitumor effects of perillyl alcohol ( $\mathrm{POH})$, a naturally occurring monoterpene related to limonene, in patients with recurrent malignant glioma. A significant proportion of these patients, who had presented with tumors refractory to standard chemoradiotherapy, responded favorably to the intranasal delivery of $\mathrm{POH}{ }^{24-26}$

At the molecular level, reduced glucose availability may cause endoplasmic reticulum (ER) stress, which triggers the unfolded protein response (UPR) cellular process, consisting of an interplay of antagonistic mechanisms; the low to moderate activity is cell-protective and supports chemo resistance, but more severe conditions aggravate these mechanisms to the point in which the protective efforts are abandoned, and the cell death program is induced instead. ${ }^{27}$ As tumor cells frequently experience chronic stress conditions (due to hypoxia, hypoglycemia, acidification, oxidative stress, etc.), the protective components of their ER stress response are continuously engaged and thus, less able to neutralize additional insults that trigger the ER stress response. ${ }^{28,29}$ The ER stress/UPR process has been described as a potential therapeutic target in $\mathrm{GBM},{ }^{30}$ and this cellular mechanism has been demonstrated to be targeted by POH in GBM cells in vitro. ${ }^{31,32}$ It is thus conceivable that the concerted effect of KD-induced hypoglycemia together with $\mathrm{POH}$-induced responses may trigger severely aggravated ER stress, resulting in tumor cell apoptosis. ${ }^{22}$

Based on our successful results in the clinical setting, we are now investigating whether adherence to a KD during treatment with intranasal $\mathrm{POH}$ can further improve the therapeutic outcomes of glioma patients. In this manuscript, we report a case study of an adult patient with recurrent glioblastoma treated with this regimen.

\section{Case Presentation}

The present study was approved by our university (CAAE: 14613313.8.0000.5243), and was performed at the university hospital. The patient signed a written informed consent form prior to enrolling in the clinical trial combining KD with intranasal delivery of $\mathrm{POH}$ to assess the therapeutic efficacy of this regimen. The $\mathrm{POH}$ was formulated for intranasal delivery, and the preparation was supplied by a multidisciplinary laboratory of Pharmaceutical Sciences at the Universidade Federal do Rio de Janeiro, according to BR Patent Number PI 0107262-5. The KD was administered concomitantly with daily inhalation of POH for three months. Perillyl alcohol (55 mg; 0.3\% v/v) was administered by inhalation 4 times a day, totaling $266.8 \mathrm{mg} / \mathrm{a}$ day.

A 54-year-old Caucasian man with no significant past medical record or family history of brain tumor or neurological disorders presented with a seizure in September 2014. A magnetic resonance imaging (MRI) brain scan revealed a regular space-occupying lesion in the left temporal-parietal lobe that was enhanced with gadolinium. The patient underwent a left temporal craniotomy with radical resection of the primary brain tumor in January 2015. Following surgery, tumor resection was confirmed by an MRI scan. The diagnosis of malignant glioma was confirmed based on complex histological features characterized by ischemic necrosis and glomeruloid microvascular proliferation.

The immunohistochemical analysis was negative for 06-methylguanine-methyltransferase (MGMT) methylation, and failed to detect mutations in the isocitrate dehydrogenase (IDH) 1 and 2 genes. The patient underwent concomitant radiation therapy (59.4 Gy total) with chemotherapy (temozolomide [TMZ] 75 mg every day for 6 weeks). Then, after the conclusion of the radiation therapy, during the adjuvant phase, the patient received TMZ (150-200 mg) on a 28-day cycle with 5 days on and 23 days off for 3 cycles. In addition, the patient was treated for seizures and remained asymptomatic for eight months. At this moment (September 2015) the patient presented with complaints of dizziness and headache. A new brain MRI revealed the presence of a left temporal mass with an intense surrounding vasogenic edema. The patient underwent an additional cycle 
of TMZ treatment, but a new MRI scan showed no reduction in the tumor lesion. The treatment was withdrawn in December 2015 because the patient was refractory to it, and presented clinical adverse effects (headache, thrombocytopenia, seizures), with an MRI scan showing no reduction in the tumoral lesion, and the patient was then considered out of therapeutic possibilities and referred to supportive (palliative) treatment. In January 2016, the patient was then enrolled in the clinical trial with KD in combination with intranasal delivery of $\mathrm{POH}$.

The anthropometric and biochemical status of the patient was assessed at the time of inclusion in the study. The KD was prescribed according to the following distribution: energy (25 kcal $/ \mathrm{kg}$ ); $1.5 \mathrm{~g} / \mathrm{kg}$ protein; 25\% carbohydrate; and $50 \%$ lipids (cholesterol $\leq 200 \mathrm{mg} /$ day; saturated fat $<7 \%$; polyunsaturated fat $<10 \%$, monounsaturated fat $<20 \%$, and fibers between $20-30 \mathrm{~g} /$ day). ${ }^{33}$ The levels of ketone bodies in the urine were measured $(15 \mathrm{mg} / \mathrm{dl})$, and confirmed the adherence to the KD. The KD was well-tolerated, without relevant changes in nutritional status, and no adverse symptoms were reported. The levels of ketone bodies remained between $5-15 \mathrm{mg} / \mathrm{dl}$ throughout the duration of the treatment. A complete list of the parameters analyzed before and 3 months after adherence to the KD are shown in (-Table 1).

At the end of the study, the patient presented with a weight loss of $4.36 \%$; a decrease in body fat of $8.5 \%$, especially in the abdominal region ( $\downarrow 10 \mathrm{~cm}$ waist circumference [WC]); an 8.8\%-increase in water retention; and increases in bone mass (2\%) and muscle mass (1\%). The KD reduced the total cholesterol level, the low-density lipoprotein (LDL) cholesterol and the triglycerides levels, improving the lipid profile, although it also reduced the high-density lipoprotein (HDL) cholesterol level. The fasting blood glucose levels did not change ( $\mathbf{- T a b l e ~} \mathbf{1}$ ).

A follow-up MRI scan conducted after 3 months of KD combined with intranasal $\mathrm{POH}$ therapy revealed marked reduction of the enhancing lesion (-Fig. 1) and significant clinical improvement. At three months after the completion of the therapeutic regimen, the patient was still being treated with low dose anti-seizure medication but no steroidal drugs. There were no signs of delayed toxicity or adverse events caused by the combined $\mathrm{KD} /$ intranasal $\mathrm{POH}$ treatment (data not shown).

\section{Discussion}

Herein we report a case study of a patient with recurrent GBM that has been successfully treated with KD concomitantly with $\mathrm{POH}$ inhalation for three months without any side effects. As a result, the patient showed tumor regression and reduced peritumoral edema, which led to an overall improvement in quality of life and lower frequency of seizures.

The severity of the peritumoral brain edema significantly influences the glioma prognosis by promoting tumor cell invasion and increasing morbidity. ${ }^{4,25}$ Increased diffusion of extracellular matrix components rich in proteases and

Table 1 Anthropometric and biochemical parameters before and after KD

\begin{tabular}{|l|l|l|l|l|}
\hline Parameters & Before KD & Results & After KD & Results \\
\hline Body mass $(\mathrm{kg})$ & 68.7 & $* * *$ & 65.7 & $\downarrow 3 \mathrm{~kg} ; \downarrow 4.4 \%$ \\
\hline BMI $\left(\mathrm{kg} / \mathrm{m}^{2}\right)$ & 23.7 & eutrophic & 22.7 & eutrophic \\
\hline WC $(\mathrm{cm})$ & 90.5 & $\begin{array}{l}\text { no risk of metabolic } \\
\text { complications }\end{array}$ & 80 & no risk of metabolic complications \\
\hline AC $(\mathrm{cm})$ & 30.5 & $94.4 \%$ (eutrophic) & 27.5 & $85.1 \%$ (mild thinness) \\
\hline TS $(\mathrm{cm})$ & 10 & $83.3 \%$ (mild thinness) & 8 & $66.7 \%$ (severe thinness) \\
\hline AMC $(\mathrm{cm})$ & 27.4 & $97.5 \%$ (eutrophic) & 25 & $89 \%$ (mild thinness) \\
\hline Biochemical Tests & Before $\mathrm{KD}$ & After KD & Reference Values \\
\hline Total cholesterol $(\mathrm{mg} / \mathrm{dL})$ & $211 \mathrm{mg} / \mathrm{dL}$ & $170 \mathrm{mg} / \mathrm{dL}$ & normal range $<200 \mathrm{mg} / \mathrm{dL}^{\text {a }}$ \\
\hline LDL cholesterol $(\mathrm{mg} / \mathrm{dL})$ & $113 \mathrm{mg} / \mathrm{dL}$ & $93 \mathrm{mg} / \mathrm{dL}$ & normal range $<100 \mathrm{mg} / \mathrm{dL}^{\text {a }}$ \\
\hline HDL cholesterol $(\mathrm{mg} / \mathrm{dL})$ & $80 \mathrm{mg} / \mathrm{dL}$ & $61 \mathrm{mg} / \mathrm{dL}$ & normal range $>60 \mathrm{mg} / \mathrm{dL}^{\mathrm{a}}$ \\
\hline Triglycerides $(\mathrm{mg} / \mathrm{dL})$ & $92 \mathrm{mg} / \mathrm{dL}$ & $81 \mathrm{mg} / \mathrm{dL}$ & normal range $<150 \mathrm{mg} / \mathrm{dL}^{\mathrm{a}}$ \\
\hline Fasting glucose $(\mathrm{mg} / \mathrm{dL})$ & $77 \mathrm{mg} / \mathrm{dL}$ & $74 \mathrm{mg} / \mathrm{dL}$ & normal range $<100 \mathrm{mg} / \mathrm{dL}^{\mathrm{b}}$ \\
\hline Urine ketone bodies & negative & positive & positive $\left(5-150 \mathrm{mg} / \mathrm{dL}^{2}\right.$ \\
\hline
\end{tabular}

Abbreviations: AC, arm circumference (men age 50-54.9 years, P50 at $32.3 \mathrm{~cm}$ ); adequacy percentage of normal range $90-110 \%$; mild thinness 80-90\% (NHANES II); AMC, arm muscle circumference (men aged 45-54.9 years, P50 at $28.1 \mathrm{~cm}$ ); adequacy percentage of normal range > 90\%; mild thinness =90\% (NHANES II); BMI, body mass index (normal range (18.5-24.9); (WHO, 1995; WHO, 1997); HDL, high-density lipoprotein; KD, ketogenic diet; LDL, low-density lipoprotein; TS, triceps skinfold (men age 50-54.9 years, P50 at $12 \mathrm{~cm}$ ); adequacy percentage of normal range 90-110\%; severe thinness < 70\% (NHANES II), WC, waist circumference (men increased risk of metabolic complications $\geq 94$ cm); Associação Brasileira para Estudo da Obesidade e SíndromeMetabólica (ABESO, 2009). ${ }^{4,5}$

Notes: Biochemical tests: ${ }^{\mathrm{V}} \mathrm{V}$ Brazilian Guideline to Dyslipidemias and Prevention of Atherosclerosis (2013); ${ }^{\circ}$ Brazilian Guideline to Diabetes 2015-2016 (2015) Urine ketone bodies: ChoiceLine 10 Urinalysis - Roche. 
$05 / 12 / 15$
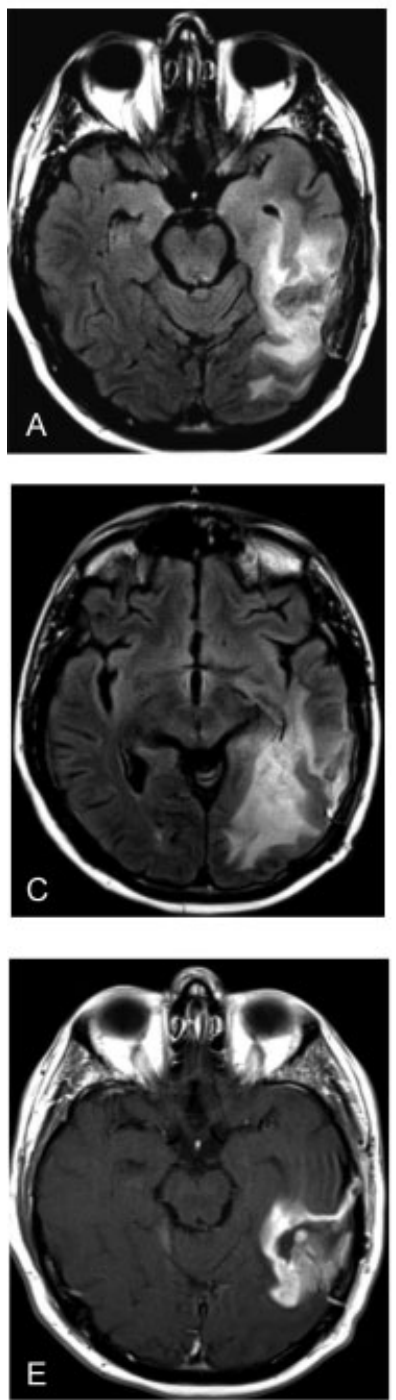

$21 / 03 / 16$
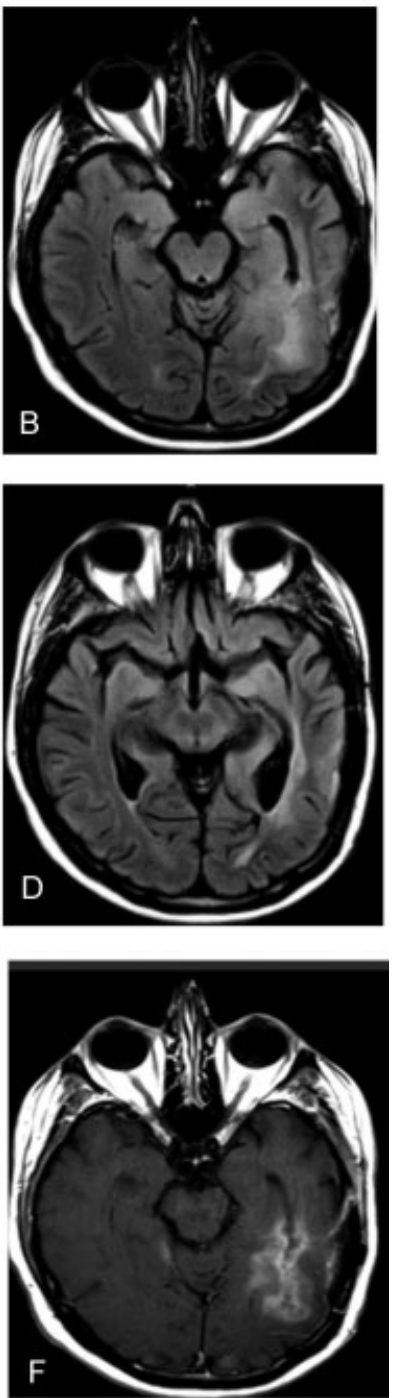

Fig. 1 Effect of ketogenic diet concomitant with perillyl alcohol inhalation in recurrent glioblastoma multiforme (GBM) patient. Representative magnetic resonance imaging (MRI) scans show marked reduction of peritumoral edema and tumor size image after 3 months of treatment $(B, D, F)$ in comparison with the first image obtained before the treatment (A, C, E). Brain MRI axial fluid-attenuated inversion recovery (FLAIR) (A-D) and T1-weighted image (T1W) with contrast (E, F).

tumor-derived growth factors into the peritumoral stroma during tumor progression further modifies the microenvironment and promotes neovascularization. ${ }^{34}$ Since the reduction in the peritumoral edema in animals that were fed the KD appears to be correlated with a decrease in the expression levels of several proteins involved in malignant progression, adherence to a KD might also represent a relevant tool to halt tumor progression. ${ }^{35}$ Our results showing a marked reduction in the peritumoral edema following our therapeutic regimen combining the administration of a $\mathrm{KD}$ and intranasal $\mathrm{POH}$ were encouraging and consistent with the literature, suggesting that the extent of the peritumoral edema may impact the overall survival in patients with GBM. ${ }^{2,36}$
Moreover, our results demonstrating a reduction in the frequency of seizure episodes in a patient with recurrent GBM following combined administration of the KD and intranasal $\mathrm{POH}$ are consistent with an increasing body of data demonstrating the value of using a KD to manage patients with intractable epilepsy. ${ }^{12,37}$ Importantly, seizures are often refractory to medication in patients with GBM, and can persist after surgery. ${ }^{8}$ This is a major concern in the management of patients with GBM, as epilepsy develops in $29-49 \%$ of the patients diagnosed with brain tumors. ${ }^{7,38}$ In this context, tumor-related epilepsy is a condition that requires an integrated treatment approach due to the severity of the disease. ${ }^{39}$ An adequate high-fat, low-carbohydrate, protein-based KD might be useful in the treatment and management of brain tumors because it appears to interfere with key epileptogenic mechanisms involving changes in $\mathrm{pH}$, neurotransmitters, ion levels, and in the expression of voltage-dependent channels and receptors in the tumoral and peritumoral brain tissues. ${ }^{9,21}$

Overall, the results of this study demonstrated that the KD was well-tolerated and compatible with previous clinical findings. The KD-induced hypoglycemia can potentially be an adjuvant to standard treatments, such as surgery and chemoradiation, and also possibly to novel regimens, such as intranasal $\mathrm{POH}$, in the recurrence setting.

Conflicts of Interest

Authors have no conflicts of interest.

\section{References}

1 Stupp R, Mason WP, van den Bent MJ, et al; European Organisation for Research and Treatment of Cancer Brain Tumor and Radiotherapy Groups; National Cancer Institute of Canada Clinical Trials Group. Radiotherapy plus concomitant and adjuvant temozolomide for glioblastoma. N Engl J Med 2005;352(10): 987-996

2 Durst CR, Raghavan P, Shaffrey ME, et al. Multimodal MR imaging model to predict tumor infiltration in patients with gliomas. Neuroradiology 2014;56(02):107-115

3 Paw I, Carpenter RC, Watabe K, Debinski W, Lo HW. Mechanisms regulating glioma invasion. Cancer Lett 2015;362(01):1-7

4 Wu CX, Lin GS, Lin ZX, et al. Peritumoral edema on magnetic resonance imaging predicts a poor clinical outcome in malignant glioma. Oncol Lett 2015;10(05):2769-2776

5 Armstrong TS, Grant R, Gilbert MR, Lee JW, Norden AD. Epilepsy in glioma patients: mechanisms, management, and impact of anticonvulsant therapy. Neuro-oncol 2016;18(06):779-789

6 Bruna J, Miró J, Velasco R. Epilepsy in glioblastoma patients: basic mechanisms and current problems in treatment. Expert Rev ClinPharmacol 2013;6(03):333-344

7 Kargiotis O, Markoula S, Kyritsis AP. Epilepsy in the cancer patient. Cancer ChemotherPharmacol 2011;67(03):489-501

8 Pallud J, Capelle L, Huberfeld G. Tumoralepileptogenicity: how does it happen? Epilepsia 2013;54(Suppl 9):30-34

9 Shamji MF, Fric-Shamji EC, Benoit BG. Brain tumors and epilepsy: pathophysiology of peritumoral changes. Neurosurg Rev 2009; 32(03):275-284, discussion 284-286

10 Allen BG, Bhatia SK, Anderson CM, et al. Ketogenic diets as an adjuvant cancer therapy: History and potential mechanism. Redox Biol 2014;2:963-970

11 Cross H. Epilepsy: behavioural, psychological, and ketogenic diet treatments. BMJ ClinEvid 2015 
12 Rho JM. How does the ketogenic diet induce anti-seizure effects? Neurosci Lett 2017;637:4-10

13 Strowd RE III, Grossman SA. The Role of Glucose Modulation and Dietary Supplementation in Patients With Central Nervous System Tumors. Curr Treat Options Oncol 2015;16(08):36

14 Mobbs CV, Mastaitis J, Isoda F, Poplawski M. Treatment of diabetes and diabetic complications with a ketogenic diet. J Child Neurol 2013;28(08):1009-1014

15 Paoli A, Bianco A, Damiani E, Bosco G. Ketogenic diet in neuromuscular and neurodegenerative diseases. BioMed Res Int 2014; 2014:474296

16 Champ CE, Palmer JD, Volek JS, et al. Targeting metabolism with a ketogenic diet during the treatment of glioblastoma multiforme. J Neurooncol 2014;117(01):125-131

17 Seyfried TN, Flores R, Poff AM, D'Agostino DP, Mukherjee P. Metabolic therapy: a new paradigm for managing malignant brain cancer. Cancer Lett 2015;356(2 Pt A):289-300

18 Liberti MV, Locasale JW. The Warburg Effect: How Does it Benefit Cancer Cells? Trends Biochem Sci 2016;41(03):211-218

19 Lu J, Tan M, Cai Q. The Warburg effect in tumor progression: mitochondrial oxidative metabolism as an anti-metastasis mechanism. Cancer Lett 2015;356(2 Pt A):156-164

20 Bhattacharya B, Mohd Omar MF, Soong R. The Warburg effect and drug resistance. Br J Pharmacol 2016;173(06):970-979

21 Kroemer G, Pouyssegur J. Tumor cell metabolism: cancer's Achilles' heel. Cancer Cell 2008;13(06):472-482

22 Zuccoli G, Marcello N, Pisanello A, et al. Metabolic management of glioblastoma multiforme using standard therapy together with a restricted ketogenic diet: Case Report. NutrMetab (Lond) 2010;7:33

23 Schwartz K, Chang HT, Nikolai M, et al. Treatment of glioma patients with ketogenic diets: report of two cases treated with an IRB-approved energy-restricted ketogenic diet protocol and review of the literature. Cancer Metab 2015;3:3

24 da Fonseca CO, Linden R, Futur oD, Gattass CR, Quirico-Santos T. Ras pathway activation in gliomas: a strategic target for intranasal administration of perillyl alcohol. Arch ImmunolTherExp (Warsz) 2008;56(04):267-276

25 Da Fonseca CO, Silva JT, Lins IR, et al. Correlation of tumor topography and peritumoral edema of recurrent malignant gliomas with therapeutic response to intranasal administration of perillyl alcohol. Invest New Drugs 2009;27(06):557-564
26 DA Fonseca CO, Teixeira RM, Silva JC, et al. Long-term outcome in patients with recurrent malignant glioma treated with Perillyl alcohol inhalation. Anticancer Res 2013;33(12):5625-5631

27 Wagner M, Moore DD. Endoplasmic reticulum stress and glucose homeostasis. CurrOpinClinNutrMetab Care 2011;14(04):367-373

28 Schonthal AH. Targeting endoplasmic reticulum stress for cancer therapy. Front Biosci (Schol Ed) 2012;4:412-431

29 Kato $\mathrm{H}$, Nishitoh H. Stress responses from the endoplasmic reticulum in cancer. Front Oncol 2015;5:93

30 Peñaranda Fajardo NM, Meijer C, Kruyt FA. The endoplasmic reticulum stress/unfolded protein response in gliomagenesis, tumor progression and as a therapeutic target in glioblastoma. BiochemPharmacol 2016;118:1-8

31 Cho HY, Wang W, Jhaveri N, et al. Perillyl alcohol for the treatment of temozolomide-resistant gliomas. Mol Cancer Ther 2012; 11(11):2462-2472

32 Henker C, Kriesen T, Fürst K, et al. Effect of 10 different polymorphisms on preoperative volumetric characteristics of glioblastoma multiforme. J Neurooncol 2016;126(03):585-592

33 Brazilian Cardiology Archives. Brazilian guideline of dyslipidemia and prevention of atherosclerosis. Available in: http://publicações.cardiol.br/2014/diretrizes.asp. Acess2016 (November/11).

34 Zidlik V, Brychtova S, Uvirova M, Ziak D, Dvorackova J. The changes of angiogenesis and immune cell infiltration in the intra- and peri-tumoral melanoma microenvironment. Int J MolSci 2015; 16(04):7876-7889

35 Woolf EC, Curley KL, Liu Q, et al. The Ketogenic Diet Alters the Hypoxic Response and Affects Expression of Proteins Associated with Angiogenesis, Invasive Potential and Vascular Permeability in a Mouse Glioma Model. PLoS One 2015;10(06):e0130357

36 Lin ZX. Glioma-related edema: new insight into molecular mechanisms and their clinical implications. Chin J Cancer 2013; 32(01):49-52

37 Sampaio LP. Ketogenic diet for epilepsy treatment. ArqNeuropsiquiatr 2016;74(10):842-848

38 Kaur T, Manchanda S, Saini V, Lakhman SS, Kaur G. Efficacy of Anti-Epileptic Drugs in the Treatment of Tumor and Its Associated Epilepsy: An in vitro Perspective. Ann Neurosci 2016;23(01): 33-43

39 Lillis KP, Dulla C, Maheshwari A, et al. WONOEP appraisal: molecular and cellular imaging in epilepsy. Epilepsia 2015;56(04):505-513 